\title{
Removal of cholesterol during milk fat fractionation by supercritical carbon dioxide
}

\author{
VEIKKO KANKARE and MARTTI ALKIO
}

\begin{abstract}
KANKARE, V. \& AlKıo, M. 1993. Removal of cholesterol during milk fat fractionation by supercritical carbon dioxide. Agric. Sci. Finl. 2: 387-393. (Agric. Res. Centre of Finland, Food Res. Inst., FIN-31600 Jokioinen and Techn. Res. Centre of Finland, Chem. Lab., Biologinkuja 7, FIN-02150 Espoo.)

Milk fat contains compounds such as aroma substances which we may want to enrich, as well as compounds such as cholesterol which we may want to remove. The utilization of SC- $\mathrm{CO}_{2}$ extraction for enriching or removing such compounds has been studied on a pilot plant scale, with the most recent experiments focusing on the removal of cholesterol. It was found that more than $99 \%$ of milk fat cholesterol could be removed using an extraction system equipped with a silica gel column. The extraction was performed under a constant pressure of $320 \mathrm{bar}$ and at a constant temperature of $52^{\circ} \mathrm{C}$. The results show that the removal of cholesterol and milk fat fractionation based on the molecule size of triglycerides can be achieved simultaneously.
\end{abstract}

Key words: supercritical extraction, milk fat, melting properties, fatty acids, removal of cholesterol

\section{Introduction}

The food industry utilizes milk fat mainly as butter and anhydrous milk fat. However, these products do not ideally meet the requirements of the industry, and a great deal of research has been conducted to find methods of modifying the milk fat to suit these requirements. The most effectively applied method industrially is fractionation based on crystallization (KANKARE 1974, WILSON 1975, BADINGS et al. 1983, DEFFENSE 1985). Active research has also been conducted to determine the suitability of supercritical extraction for milk fat fractionation (ARUL et al. 1987, KAUFMANN et al. 1982, KANKARE et al. 1989, SHISHIKURA et al. 1986, SCHLIMME 1990, SIEBER and EYER 1990, CHEN et al. 1992). Moreover, mechanical treatments such as texturization, aeration and whipping have been used to improve the applicability of milk fat (PEDERSEN 1991, ANDERSON 1991). A number of laboratory and pilot plant studies have examined the feasibility of using various molecular and shortpath distillation methods (FORSS and HoLLOWAY 1967, STORK et al. 1973, ARUL et al. 1988) as well as chemical and enzymatic interesterification and hydrogenation in milk fat treatment (TIMMEN 1978, KALO et al. 1989).

\section{Principles of supercritical carbon dioxide extraction}

Supercritical extraction means operating under conditions in which the temperature and pressure of the solvent are higher than their respective critical values, Tc and Pc. In such conditions a fluid cannot 
be changed into a liquid state by raising the pressure, even though the specific gravity of the fluid is the same as that of liquid $\mathrm{CO}_{2}$. A supercritical fluid has good dissolving properties, diffusibility and flow characteristics. Another advantage of a supercritical fluid is that its density and, consequently, its solvent power can be varied by small changes in pressure and temperature.

Besides carbon dioxide, also other gases, e.g. propane and pentane, can be utilized for supercritical extraction, but carbon dioxide has several characteristics which make it particularly suitable for use in the food industry. Its critical temperature is relatively low, $+31^{\circ} \mathrm{C}$, and its critical pressure is 74 bar. It is, therefore, very well suited for treating thermally non-stable materials. In addition, carbon dioxide is inexpensive, non-toxic and inert.

Figure 1 shows a diagram of the extraction system used in previous experiments, but equipped with an adsorption column for the removal of cholesterol for the purposes of this study.

\section{Application of supercritical extraction for milk fat fractionation}

The solubility of milk fat into a fluid increases as the extraction pressure increases. At the same time, the molecule sizes of the extractible triglycerides also increase. Fatty acids with short and medium carbon chains are concentrated in the first fractions. The concentration of long-chain fatty acids, both saturated and unsaturated, increases as the extraction proceeds and the extraction pressure rises. Despite the concentration of unsaturated fatty acids, the melting points of the fractions grow higher as the extraction advances (SHISHIKURA et al. 1986, ARUL et al. 1987, KANKARE et al. 1989, CHEN et al. 1992, KAUFMANN 1982). It has been pointed out that the high capital costs involved prevent the use of supercritical extraction solely for fractionation (BOUDREAU and ARUL 1991).

In extraction, the milk fat aroma substances with small molecule size, such as the major lactones, ketones, aldehydes, etc., are concentrated in the first fractions (KANKARE et al. 1989, ElVEVOLL
1990). The extraction method can therefore be utilized for recovering the aroma fraction from fat.

Cholesterol is also mostly concentrated in the first fractions, but elution is not complete due to three types of interaction: triglyceride $/ \mathrm{CO}_{2}$, triglyceride/cholesterol and cholesterol/ $\mathrm{CO}_{2}$. A more complete separation of cholesterol has, however, been achieved by multi-phase extraction or by the use of adsorbents in connection with extraction (SHISHIKURA et al. 1986).

The results of our first two series of experiments studying the fractionation of milk fat, separation of aroma substances and distribution of cholesterol between the different fractions have been published previously (KANKARE et al. 1989).

\section{Objective of the study}

The aim of the present study was to investigate whether cholesterol could be adsorbed by supercritical extraction under a constant pressure and temperature, when the extraction system was equipped with a silica gel adsorption column. At the same time, the aim was to examine the fat fractions in terms of their fatty acid composition and melting properties.

\section{Material and methods}

The study was carried out with anhydrous milk fat. The following methods were applied for fat analysis:

The fatty acid compositions of milk fat and its fractions were determined with a capillary column (Chrompack CP - Sil 88) on a gas chromatograph (ANTILA and KANKARE 1983).

The melting and crystallization properties of the fats were determined with a differential scanning calorimeter, Perkin Elmer DSC-4. The cooling and heating rates were $8^{\circ} \mathrm{C} / \mathrm{min}$ (KANKARE and ANTILA 1986).

The total cholesterol content of the fats was determined from the fraction of unsaponifiables with a gas chromatograph. 


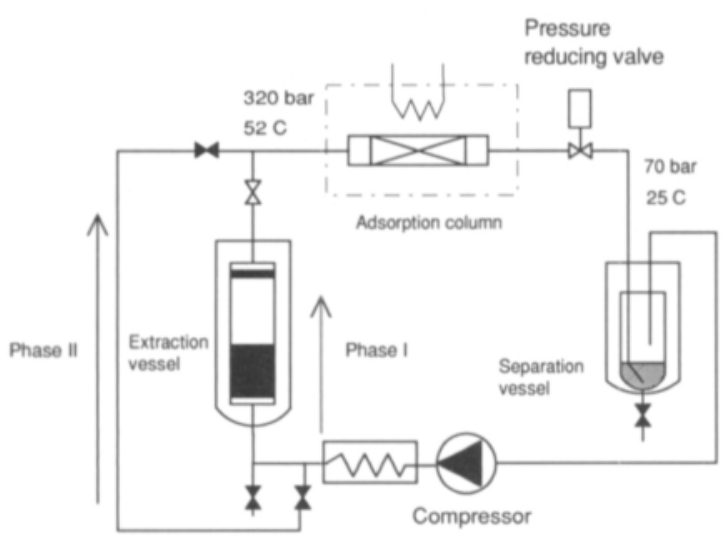

Fig. 1. Diagram of the extraction system.

The extraction experiments with supercritical carbon dioxide were conducted using a 4-litre Nova Werke AG pilot extractor.

A diagram of the extraction equipment used in this study is shown in Figure 1.

In this experiment, the melted milk fat was first poured into a sample vessel located inside the extraction vessel and equipped with sinters at both ends. After sealing the lid, the equipment was pressurized. Extraction was performed in three phases:

1. The supercritical carbon dioxide was fed through the extraction cartridge and the adsorption column. The column contained approx. $960 \mathrm{~g}$ of Merck Si60 silica gel, particle size 15 $45 \mu \mathrm{m}$. The purpose of the silica gel was to adsorb the cholesterol in the fluid. The silica gel had been activated before the experiment by keeping it overnight at a temperature of $+105^{\circ} \mathrm{C}$.

2. When the extraction of milk fat into the separation vessel ceased, the extraction vessel bypass valve was opened and pure carbon dioxide was conducted through the column in order to partially flush the adsorbed triglycerides.

3. After extraction, approx. 1.51 of $+50^{\circ} \mathrm{C}$ ethanol was pumped through the adsorption column to dissolve the residual triglycerides and cholesterol adsorbed in the column. The ethanol was evaporated using a rotary evaporator.

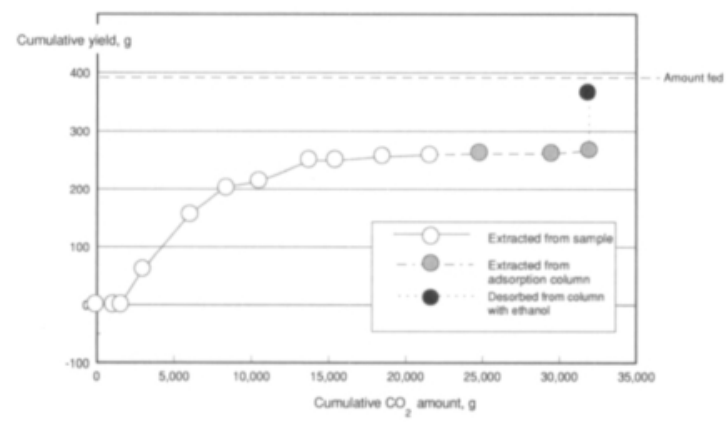

Fig. 2. The progress of extraction.

\section{Results}

A graphic illustration of the progress of the extraction conducted for this study is shown in Figure 2, and the yields and other extraction data are given in Table 1.

In this experiment, $94.4 \%$ of the amount fed was recovered in the different fractions. The remaining $5.6 \%(21.8 \mathrm{~g})$ was probably left in the column even after desorption. It is likely that the amount of ethanol used for desorption, $1.5 \mathrm{l}$, was too small in relation to the amount of adsorbent.

At the beginning of the experiment, triglycerides were adsorbed totally in the silica gel (See Fig. 2.). Once the saturation point had been reached, the amounts of triglyceride entering and leaving the column became equal, i.e., the triglycerides passed through the column. This occurred within the time range of 16-100 minutes corresponding to a $\mathrm{CO}_{2}$ consumption of $1520-8340 \mathrm{~g}$, represented by the straight portion of the extraction curve in Figure 2. In the second phase, the extraction vessel was bypassed, and now the fluid leaving the column contained $0.07-0.21 \%$ of triglycerides. As the triglyceride concentration in the adsorbent was $10.5 \%$, the coefficient calculated for triglyceride distribution between the mobile and the solid phase was approx. 100 (pressure $320 \mathrm{bar}$, temperature $52^{\circ} \mathrm{C}$ ).

Table 2 shows the cholesterol content of the original milk fat and its main fractions (yield over $8 \mathrm{~g}$ ). The table shows that it was possible to remove over $99 \%$ of the cholesterol by using an adsorption column. When pure $\mathrm{CO}_{2}$ was used to flush the 
Table 1. Extraction data and yields.

Extraction of anhydrous milk fat: amount fed $389.1 \mathrm{~g}$.

Extraction conditions:

pressure 320 bar,

temperature $52^{\circ} \mathrm{C}$.

\begin{tabular}{|c|c|c|c|c|c|c|}
\hline Sample & $\begin{array}{l}\text { Time } \\
\text { min }\end{array}$ & $\begin{array}{c}\text { Yield } \\
\mathrm{g}\end{array}$ & $\begin{array}{c}\text { Cumulative } \\
\text { yield, } g\end{array}$ & $\begin{array}{c}\text { Cumulative } \\
\text { yield, } \%\end{array}$ & $\begin{array}{c}\mathrm{CO}_{2} \text { flow } \\
\mathrm{kg} / \mathrm{h}\end{array}$ & $\begin{array}{c}\text { Cumulative } \\
\mathrm{CO}_{2} \\
\text { amount }\end{array}$ \\
\hline 1 & 16 & 0.0 & 0.0 & 0.0 & 5.7 & 1520 \\
\hline 2 & 30 & 59.2 & 59.2 & 15.2 & 6.1 & 2943 \\
\hline 3 & 60 & 96.8 & 156.0 & 40.1 & 6.1 & 5993 \\
\hline 4 & 100 & 47.4 & 203.4 & 52.3 & 3.5 & 8340 \\
\hline 5 & 120 & 8.9 & 212.3 & 54.6 & 6.4 & 10473 \\
\hline 6 & 150 & 36.7 & 249.0 & 64.0 & 6.7 & 13823 \\
\hline 7 & 180 & 6.2 & 255.2 & 65.6 & 9.6 & 18395 \\
\hline 8 & 215 & 3.1 & 258.3 & 66.4 & 5.4 & 21545 \\
\hline \multicolumn{7}{|c|}{..-Column flushed with supercritical carbon dioxide... } \\
\hline 9 & 250 & 2.2 & 260.5 & 66.9 & 7.0 & 24812 \\
\hline 10 & 310 & 5.0 & 265.5 & 68.2 & 7.0 & 31812 \\
\hline \multicolumn{7}{|c|}{..- Column flushed with $50^{\circ} \mathrm{C}$ ethanol-.. } \\
\hline 11 & & 100.9 & 366.4 & 94.2 & & \\
\hline \multicolumn{7}{|c|}{..-Raffinate (residue)... } \\
\hline & & 0.9 & 367.3 & 94.4 & & \\
\hline
\end{tabular}

Table 2. Cholesterol content of original milk fat and its fractions.

\begin{tabular}{cc}
\hline Fraction & Cholesterol mg/g \\
\hline Original milk fat & 2.80 \\
2 & $>0.03$ \\
3 & $>0.03$ \\
4 & $>0.03$ \\
5 & $>0.03$ \\
6 & $>0.03$ \\
$10^{1}$ & 7.60 \\
$11^{2}$ & 3.03 \\
\hline
\end{tabular}

I flushed from the column with supercritical carbon dioxide

2 flushed from the column with ethanol

column, cholesterol was desorbed from the column as indicated by the high cholesterol content of fraction No. 10 in Table 2. This suggests that the distribution factors between silica gel/ $/ \mathrm{CO}_{2}$ and silica gel/CO $2 /$ fat differ considerably.
Table 3 gives the fatty acid composition of the main fractions as weight percentages.

The fatty acid composition of the fractions (2-6) obtained by this extraction under a constant pressure was very similar to the fatty acid composition acquired earlier under a variable pressure, 100-400 bar (KANKARE et al. 1989). In both cases, the shortchain and medium-chain fatty acids were concentrated in the first extracts, and the saturated as well as the unsaturated long-chain fatty acids in the last extracts.

The melting curves of the original fat and the extracts are shown in Figures 3 and 6. The first fractions change into a liquid state at a lower temperature than the last fractions, in spite of the fact that the fractions obtained at the end of the extraction contain more unsaturated fatty acids than the first fractions. This goes to show that also under a constant pressure, triglycerides are probably extracted mainly in the order indicated by their molecular weight, as has been found to be the case 
Table 3. Fatty acid composition of milk fat and its extracts, weight percentages.

\begin{tabular}{|c|c|c|c|c|c|c|c|c|}
\hline \multirow[t]{2}{*}{ Fatty acid } & \multirow{2}{*}{$\begin{array}{l}\text { Original } \\
\text { milk fat }\end{array}$} & \multicolumn{7}{|c|}{ Extract } \\
\hline & & 2 & 3 & 4 & 5 & 6 & 10 & 11 \\
\hline $\mathrm{C}_{4}$ & 3.66 & 5.86 & 3.87 & 3.94 & 2.68 & 1.63 & 1.73 & 2.94 \\
\hline $\mathrm{C}_{6}$ & 2.89 & 4.68 & 3.07 & 3.21 & 2.31 & 1.42 & 1.55 & 2.12 \\
\hline $\mathrm{C}_{8}$ & 1.82 & 2.82 & 1.91 & 2.07 & 1.61 & 1.05 & 1.05 & 1.35 \\
\hline $\mathrm{C}_{10}$ & 3.73 & 5.29 & 3.99 & 4.27 & 3.73 & 2.75 & 2.41 & 2.80 \\
\hline $\mathrm{C}_{12}$ & 3.89 & 5.20 & 4.18 & 4.17 & 4.01 & 3.30 & 2.77 & 3.15 \\
\hline $\mathrm{C}_{14}$ & 12.00 & 14.31 & 12.66 & 12.12 & 12.20 & 11.31 & 9.43 & 10.73 \\
\hline $\mathrm{C}_{16}$ & 29.61 & 30.11 & 30.66 & 29.39 & 29.16 & 28.81 & 27.33 & 29.51 \\
\hline $\mathrm{C}_{16: 1} \mathrm{C}$ & 1.67 & 1.25 & 1.35 & 1.64 & 1.80 & 1.85 & 1.24 & 1.62 \\
\hline $\mathrm{C}_{18}$ & 10.49 & 7.09 & 9.55 & 9.99 & 10.41 & 11.83 & 15.13 & 12.91 \\
\hline $\mathrm{C}_{18: 1} \mathrm{~T}$ & 1.42 & 0.95 & 1.29 & 1.34 & 1.47 & 1.84 & 1.97 & 1.72 \\
\hline $\mathrm{C}_{18: 1} \mathrm{C}$ & 19.85 & 13.95 & 18.42 & 19.33 & 21.16 & 24.84 & 25.76 & 22.69 \\
\hline $\mathrm{C}_{18: 2} \mathrm{~T}$ & 0.67 & 0.34 & 0.53 & 0.55 & 0.68 & 0.76 & 0.92 & 0.59 \\
\hline $\mathrm{C}_{18: 2} \mathrm{C}$ & 1.62 & 1.19 & 1.48 & 1.49 & 1.72 & 1.81 & 1.81 & 1.49 \\
\hline $\mathrm{C}_{18: 3} \mathrm{C}$ & 0.47 & 0.39 & 0.47 & 0.46 & 0.49 & 0.54 & 0.74 & 0.35 \\
\hline Unsaturated total & 27.97 & 20.58 & 25.95 & 27.21 & 29.88 & 34.11 & 34.40 & 30.57 \\
\hline Saturated total & 72.03 & 79.42 & 74.05 & 72.79 & 70.12 & 65.89 & 65.60 & 69.43 \\
\hline
\end{tabular}

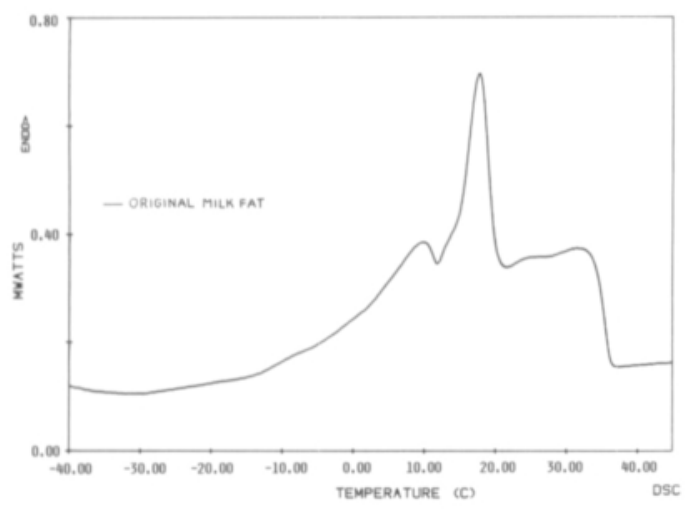

Fig. 3. Melting curve of the original milk fat.

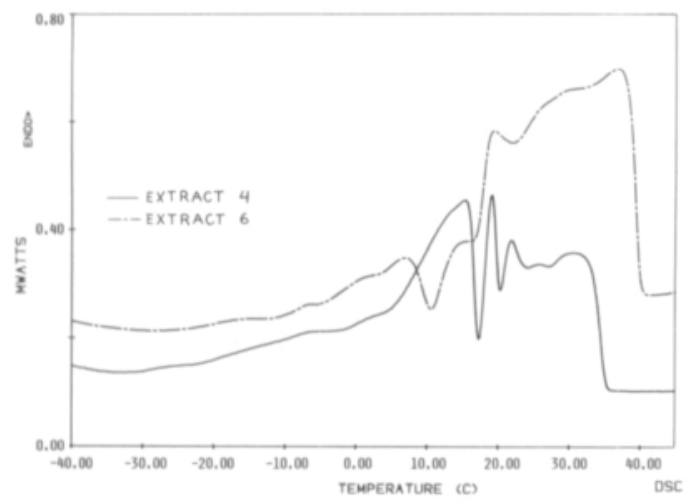

Fig. 5. Melting curves of extracts 4 and 6.

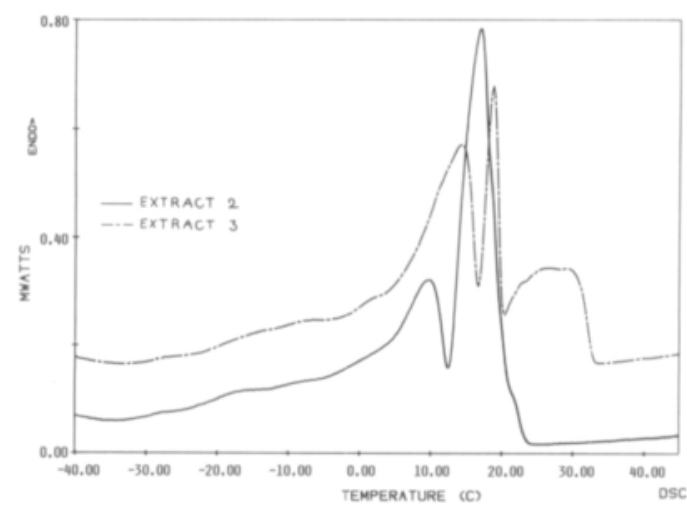

Fig. 4. Melting curves of extracts 2 and 3.

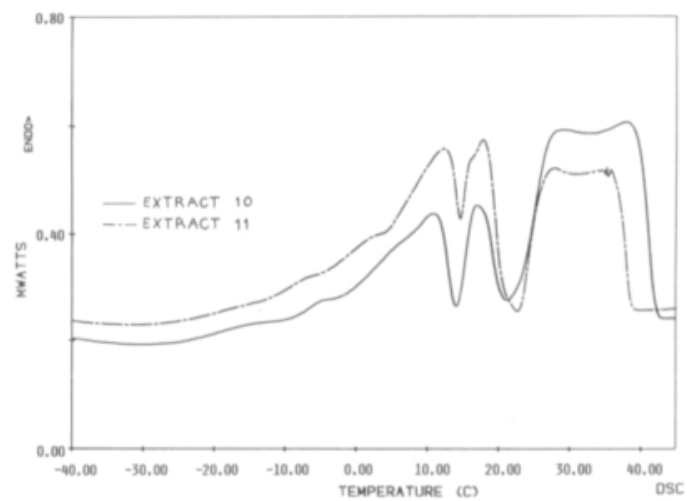

Fig. 6. Melting curves of extracts 10 and 11. 
in extraction under a gradually increasing carbon dioxide pressure (KANKARE et al. 1989). This is due to the higher vapour pressures of the low molecular weight triglycerides and the short-chain fatty acids.

The experiment showed that by connecting a cholesterol adsorbing silica gel column to the supercritical extractor it is possible to achieve both the removal of cholesterol from milk fat and fractionation based primarily on molecule size.

\section{Discussion}

By using an adsorbent column in this experiment it was possible to remove over $99 \%$ of the cholesterol from extracts 2-6. In a similar experiment, SHISHIKURA et al. (1986) achieved a cholesterol content of $0.013 \%$, i.e., over $96 \%$ of the cholesterol was removed from the fat. The more efficient removal of cholesterol in the present study was probably due to the larger amount of adsorbent used.

When extraction is performed without an adsorption column by increasing the extraction pressure, it is possible to concentrate cholesterol into the first extracts, but some cholesterol is still found in the other extracts (KANKARE et al. 1989, ElVEVOLL 1990, CHEN et al. 1992). This should enable selective cholesterol extraction from fat by using continuous countercurrent $\mathrm{CO}_{2}$ extraction and a low extraction pressure.

In the extractions conducted for this study, fractionation in regard to fatty acids was found to occur in the same manner as in extraction without an adsorbent column (ARUL et al. 1987, KANKARE 1989, ElVEVOLL 1990). The melting properties of the extracts were also similar regardless of whether an adsorption column was used or not (KAUFMANN 1982, KANKARE et al. 1989, CHEN et al. 1992). The melting points of the fractions were found to become systematically higher as the extraction proceeded.

The study indicates that the removal of cholesterol and the fractionation of fat on the basis of different fatty acid composition can be achieved simultaneously by performing the milk fat extraction using supercritical carbon dioxide and connecting an adsorbent column filled with silica gel to the extraction system.

\section{References}

Anderson, K. 1991. Modified "butters". Bulletin of the International Dairy Federation Nro 260: 17-18.

AnTILA, V. \& Kankare, V. 1983. The fatty acid composition of milk lipids. Milchwissenschaft 38, 8: 478-481.

Arul, J., Boudreau, A., Makhlouf, J., Tardif, R. \& Bel. LAVIA, T.J. 1988. Fractionation of anhydrous milk fat by short-path distillation. Amer. Oil Chem. Soc. 65: 16421646.

-, Boudreau, A., Makhlouf, J., Tardif, R. \& SahasRABUDHE, M.R. 1987. Fractionation of anhydrous milk fat by supercritical carbon dioxide. J. of Food Sci. 52, 5: 1231-1236.

Badings, H.T., SchaAp, J.E., Jong, C. de \& Hagedcorn, H.G. 1983. An analytical study of fractions obtained by stepwise cooling of melted milk fat. 1. Methodology. Milchwiss. 38: 95-97.

BOUdREAU, A. \& ARUL, J. 1991. Fractionation by supercritical fluids in monograph on utilizations of milkfat. Bulletin of the International Dairy Federation Nro 260: 8-9.

Chen, H., Schwartz, I. \& Sponos, A. 1992. Fractionation of butter oil by supercritical carbon dioxide. J. Dairy Sci. 75: $2659-2669$.

DEFFENSE, E. 1985. Theory and practice of fractionation.
Seminar "Teach-In" on fat modification. Chester England. Society of Chemical Industry: Oils \& Fats Group. $31 \mathrm{p}$.

ElveVolL, E.O. 1990. Superkritisk ekstraksjon av melkefett in Sammanfattningen av förefrag in Symposium: Mjölkfettets roll - I dag och i morgon. Nordisk mejeritekniskt råd: $51-60$.

Forss, D.A. \& Holloway, G.L. 1967. Recovery of volatile compounds from butter oil. J. Amer. Oil Chem. Soc. 44: $572-575$.

Kalo, P., Huotari, H. \& Antila, M. 1989. Pseudomonas fluorescens lipase, catalysed interesterification of butter fat. Fat Sci. Technol. 91: 276-281.

KANKARE, V. 1974. Maitorasvan fraktioinnista kiteyttämällä ilman liuottimia ja lisäaineita. Meijeritieteellinen $\mathrm{Ai}$ kakauskirja 33, 2: 1-132.

— \& ANTIL.A, V. 1986. Melting characteristics of milk fat and milk fat fractions. Meijeritieteellinen Aikakauskirja 45, 1: 67-75

-, Antil.a, V., Harvala, T. \& Komppa, V. 1989. Extraction of milk fat with supercritical carbon dioxide. Milchwissenschaft 44, 7: 407-411.

Kaufmann, W., Biernoth, G., Frede, E., Merk, W., 
Precht, D. \& Timmen, H. 1982. Fractionierung von Butterfett durch Extraktion mit über kritischem $\mathrm{CO}_{2}$. Milchwissenschaft 37, 2: 92-96.

Pedersen, A. 1991. Texturization of milkfat. Bulletin of the International Dairy Federation Nro 260: 10-12.

Schlimme, E. 1990. Removal of cholesterol from milkfat. European Dairy Magazine 4: 12-21.

Shishikura, A., Funmoto, K., Kaneda, T., Kunio, A. \& SArTo, S. 1986. Modification of butter oil by extraction with supercritical carbon dioxide. Agric. Biol. Chem. 50, 5: 1209-1215.

SIEBER, R. \& EYER, H. 1990. Cholesterinentfernung aus Milchfett. Schweiz. Milchw. Forschung 19: 31-38.

Stork, W., Urbach, G., Hamilton, I.S. \& Forss, D.A. 1973. Volatile compounds in butter oil. III Recovery of added acids on $\delta$-lactones from volatile-free butter oil by coldfinger molecular distillation. J. Dairy Res. 40: 39-46.

Timmen, H. 1978. Modifizierte Milchfette: Herstellung,
Charakterisierung, Verwendung. Deutsche Milchwirtschaft 29: 1127-1134.

WILson, B.W. 1975. Techniques of fractionation of milk fat. Aust. J. Dairy Technol. 30, 1: 10-13.

Manuscript received April 1993

Veikko Kankare

Agricultural Research Centre of Finland

Food Research Institute

FIN-31600 Jokioinen, Finland

Martti Alkio

Technical Research Centre of Finland

Chemical Laboratory

Biologinkuja 7

FIN-02150 Espoo, Finland

\title{
SELOSTUS
}

\section{Kolesterolin poisto maitorasvasta ylikriittiseen hiilidioksidiuuttoon perustuvan fraktioinnin yhteydessä}

\author{
VeIKKo KANKARE ja MARTTI ALKIO \\ Maatalouden tutkimuskeskus ja Valtion teknillinen tutkimuskeskus
}

Maitorasva koostuu pääosin $(97-98 \%)$ molekyylipainoltaan erilaisista triglyserideistä. Tämä antaa hyvät mahdollisuudet erilaisten fraktiointimenetelmien käytännön sovelluksiin, joista yksi on rasvan fraktiointi ylikriittistä hiilidioksidiuuttoa käyttäen. Maitorasva sisältää yhdisteitä, kuten aromiaineita, joita halutaan rikastaa, samoin kuin yhdisteitä, kuten kolesterolia, joka halutaan poistaa. Ylikriittinen uutto soveltuu sekä yhdisteiden rikastamiseen että poistoon. $\mathrm{SC}-\mathrm{CO}_{2}$ uuton käyt- tömahdollisuuksia on selvitetty pilot plant mittakaavassa. Viimeisimmissä kokeissa on keskitytty kolesterolin poistoon. Selvitysten mukaan yli $99 \%$ maitorasvan kolesterolista voidaan poistaa maitorasvasta varustamalla uuttojärjestelmä kolesterolia adsorboivalla silikageeli-kolonnilla. Rasva uutettiin vakiopaineessa, 320 bar, ja vakiolämpötilassa $52{ }^{\circ} \mathrm{C}$. Tulokset osoittivat, että maitorasvan fraktiointi ja kolesterolin poisto voidaan tehdä samanaikaisesti. 